\title{
ENGAJAMENTO ASSOCIATIVO-SINDICAL E RECRUTAMENTO DE ELITES POLÍTICAS: TENDÊNCIAS RECENTES NOBRASIL
}

\author{
Odaci Luiz Coradini
}

\section{RESUMO}

Com base na constatação do crescimento contínuo da quantidade de políticos de atuação em âmbito nacional (deputados federais, senadores e ministros) vinculados a algum tipo de associação ou sindicato, são examinadas as relações desse fato com os respectivos trajetos sociais e com as posições no espaço político. Para tanto, consideram-se políticos vinculados a associações-sindicatos de trabalhadores urbanos, rurais e de funcionários públicos, de professores e de empresários eleitos no período de 1994 a 2003. A principal hipótese para o aumento dos usos do capital associativo com a intensificação da concorrência eleitoral posterior ao regime autoritário é a de que os processos eleitorais agregam diferentes recursos e princípios de legitimação e representação. As modalidades dessa reconversão de capital associativo em recursos políticos e a dinâmica das relações entre o engajamento associativo e a política eleitoral não decorrem de alguma regra geral, mas de configurações específicas.

PALAVRAS-CHAVE: elites políticas; capital associativo; engajamento político; militância política; representação política.

\section{INTRODUÇÃO}

Ao considerar os vínculos dos políticos com atuação em âmbito nacional e, mais especificamente, os deputados federais, senadores e ministros que assumiram entre 1994 e 2003, com as diferentes modalidades de engajamento e militância associativa e/ou sindical, a primeira constatação mais geral - é seu crescimento constante. No que tange especificamente aos deputados federais, de uma proporção de $85,6 \%$ sem qualquer vínculo desse tipo na legislatura com início em 1979, essa parcela reduziu-se (81,3\%, em 1983; 70,2\%, em 1987; 58,2\%, em 1991; 50,2\%, em 1995; 45,7\%, em 1999, e, finalmente, 44, 9\%, na legislatura com início em 2003). Portanto, mais da metade dos deputados federais passou a ter algum vínculo com associações ou sindicatos. Como a maior parte dos senadores e ministros já ocupou o cargo de Deputado Federal, é possível supor que tenha ocorrido algo semelhante com esse grupo. Tomando o conjunto dos deputados federais, senadores e ministros do período de 1994 a 2002, nada menos que 55,3\% mantêm vinculações similares. Os tipos que mais se destacam nesse crescimento referem-se a organizações de empresários ou organizações privadas em geral: de trabalhadores urbanos, trabalhadores rurais, funcionários públicos, professores (de todos os níveis), médicos, advogados, engenheiros e similares, além de associações de moradores, assistenciais, religiosas, feministas, ou de defesa da "cidadania” em geral ${ }^{1}$.

\footnotetext{
${ }^{1} \mathrm{O}$ material deste texto foi extraído de um trabalho mais amplo, no qual foram consideradas como modalidades de vinculação associativa-sindica as que seguem: associaçõessindicatos de empresários, trabalhadores urbanos, trabalhadores rurais e de funcionários públicos; de professores, de todos os graus de ensino; de médicos, advogados, engenheiros; de moradores, assistenciais, religiosas, feministas e de defesa de "direitos" ou de "cidadania"; organizações estudantis; clubes esportivos e similares; e, por fim, associações de prefeitos, vereadores, deputados e similares. Seguindo as sugestões de Gaxie e Offerlé (1985), foram considerados os vínculos associativo-sindicais tanto com organizações de "trabalhadores" como de "empresários" ou outras categorias. Naquele trabalho, além da vinculação associativa-sindica dos políticos, foram analisadas também as relações entre a sindicalização da população economicamente ativa brasileira e, no que tange aos políticos, o exercício de cargos de "confiança” como modalidade de entrada na carreira política (ver CORADINI, 2005). No presente texto, tendo em vista o espaço disponível, somente são tratadas as relações com associações-sindicatos de empresários, de trabalhadores urbanos, trabalhadores rurais, de funcionários públicos, de professores e, por fim, de médicos, advogados, engenheiros e similares.
}

Rev. Sociol. Polít., Curitiba, 28, p. 181-203, jun. 2007 
Esse aumento da proporção de políticos com vinculação com associações ou sindicatos ocorre no período de maior intensificação da concorrência eleitoral. Como já destacado para outros contextos, não existem regras que possam ser tomadas como universais quanto às relações entre engajamento partidário, associativo e outras modalidades. No caso francês, conforme o trabalho de Gaxie e Offerlé (1985, p. 113-121), mesmo na conjuntura favorável da vitória do Partido Socialista, os políticos cuja entrada ou carreira política estava baseada no capital "associativo" eram "duplamente marginais”. Em termos quantitativos, constituíam uma minoria frente ao conjunto e qualitativamente, dispunham de menos recursos. Porém, ao contextualizar esses resultados, Offerlé (1998, p. 95-96) destaca que em outros casos ocorreria o contrário, como aquele dos países escandinavos ou com partidos trabalhistas fortes. Seja como for, trata-se de desmistificar as relações entre partidos políticos e grupos de interesse, examinando suas diferentes modalidades de transações e afinidades ${ }^{2}$. No que tange à bibliografia internacional, é crescentemente destacada a tendência do recrutamento de elites políticas em determinadas profissões, geralmente, caracterizadas pelo alto capital escolar, com posição social elevada e vinculadas a determinadas esferas de atividade. Normalmente, esta literatura está centrada no estudo das bases sociais e das "carreiras” dos representantes políticos. Portanto, é atribuída menos importância às condições e mecanismos sociais de legitimação da representação política e, mais especificamente, à sua vinculação com grupos de interesse de diferentes modalida$\operatorname{des}^{3}$. No que tange ao caso brasileiro, há uma literatura relativamente ampla centrada no tratamento das relações entre o Estado ou a esfera

2 Sobre a necessidade de superar as visões reificadas das relações entre grupos de interesse e partidos políticos, mostrando as interações e as afinidades eletivas e que podem se estabelecer e se tecer mutuamente, ver Offerlé (1998, p. 127). Isso implica no estudo dos diferentes tipos de redes de interesse que perpassam as relações com os partidos e com as burocracias públicas (SAWICKI, 1987; BEZERRA, 1999).

3 Para um conjunto recente de estudos centrados na "profissionalização" da representação política, ver Borchert e Zeiss (2003). Para a comparação da evolução do recrutamento dos parlamentares em diferentes países europeus, ver Best e Cotta (2000); no que tange especificamente à França, ver Birnbaum (1994). política e a organização e representação de interesses que, em geral, enfatizam a proeminência do Executivo em detrimento do Legislativo ou da política eleitoral. Essa constatação possibilitou, inclusive, a definição do processo de expansão das políticas de garantias sociais como "cidadania regulada” (SANTOS, 1979, p. 75). Porém, via de regra, não são tomadas as relações entre o engajamento associativo-sindical e partidário e sua eventual interdependência ou exclusão entre si, bem como sua associação com outros recursos e esferas de ação.

Como os dados sinteticamente expostos nos itens seguintes parecem indicar, tanto a ocorrência de vínculos entre políticos e associações-sindicatos como as modalidades postas em prática não dependem apenas das lógicas do engajamento e militância associativa e/ou sindical ou da política eleitoral, mas de sua inserção e inter-relação com uma série de outros recursos e esferas de atuação. Dentre estes, observam-se: o grau e o tipo de formação escolar; as classificações e a inserção profissional e, mais especificamente, suas relações com a escolarização, com modalidades concorrentes de exercício profissional e seu significado, como estrutura de capital e posição social; as relações categoriais ou setoriais com o universo da política, como valores, militância e possibilidades de exercício de cargos de "confiança” ou benefícios de políticas governamentais. Nesse contexto, destacam-se ainda as condições de origem ou de chegada no que tange às relações centro-periferia e seus efeitos nos respectivos trajetos sociais e modalidades de entrada na política; e, por fim, sem qualquer pretensão de exaustão, a respectiva situação frente ao espectro das orientações políticas em concorrência, além da postura que se relaciona ao governo em voga e às oposições. Em síntese, trata-se de tomar essas relações como uma configuração específica no confronto entre modalidades legítimas de representação 4 . Por um lado, de modo condicionado pela disponibilidade e pelo grau de conversibilidade de diferentes tipos de recursos e, por outro, pelo nível da política em que se insere e pela estrutura do espaço político na conjuntura histórica em pauta.

\footnotetext{
4 Para uma discussão mais geral sobre os confrontos entre princípios de definição legítima de representação política, ver Bourdieu (1981); para uma análise do parlamento francês, ver Collovald e Gaïti (1990).
} 


\section{AS PRINCIPAIS MODALIDADES DE VÍN- CULOS ASSOCIATIVO-SINDICAIS}

Mais importante do que o crescimento quantitativo da parcela dos políticos que apresenta algum tipo de vinculação associativa-sindical em seus respectivos trajetos é sua distribuição nas diferentes modalidades desse tipo de vínculo e suas relações com outros indicadores pertinentes. Trata-se das relações dessas modalidades de vinculação com associações-sindicatos às principais ocupações na carreira, à disciplina da titulação escolar mais alta, ao montante do patrimônio econômico e à filiação partidária 5 .

Antes de apresentar as categorias, é necessária uma rápida descrição daqueles que não apresentam qualquer vínculo associativo-sindical em seus respectivos trajetos $(44,7 \%$ do universo total), que também configuram uma categoria específica. Um dos aspectos que mais distingue esses sem vinculação associativa-sindical é a escolarização, associando-se mais intensamente com alguns cursos universitários mas também com aqueles sem titulação superior. Há uma proporção mais elevada dos que cursaram direito e daqueles sem titulação universitária (26,8\% contra $19,81 \%$ do universo total).

Outro item que distingue essa categoria relaciona-se à sua principal ocupação durante a carreira, com uma proporção mais alta para aqueles “não-classificáveis” ou “outros” (7,5\% contra 4,6\% do universo total). Adicionalmente, há uma concentração maior de outras categorias, particularmente daquelas cujo trajeto consiste na administração-propriedade de empresas privadas sobre aquelas cujo trajeto é composto pela ocupação de cargos públicos de "confiança", ou ainda cuja carreira se resume à ocupação de cargos públicos eletivos (6,2\% contra $4,5 \%$ do universo total). Em síntese, no que tange à inserção social, os políticos sem vínculos associativo-sindicais tendem a apresentar um trajeto menos próximo do universo escolar; e, no que tange ao trajeto

5 Em uma primeira exploração do conjunto do material, foi aplicado um teste de correspondência múltipla, tendo como variáveis ativas: o principal tipo de associação-sindicato de vinculação, principais ocupações durante a carreira, a disciplina da titulação escolar, a filiação partidária, a profissão declarada e, por fim, o montante do patrimônio econômico. Além disso, foram utilizadas cerca de 70 variáveis ilustrativas. Para mais detalhes, ver Coradini (2005). “profissional”, mais diretamente associado à propriedade e/ou gestão de empresas privadas, ou ainda às ocupações menos codificadas.

O que mais distingue essa categoria sem qualquer vínculo associativo-sindical, contudo, é a filiação partidária e, particularmente, a freqüência mais acentuada de troca de partido. Relativamente à atual filiação (2005), a associação mais intensa ocorre com o Partido da Frente Liberal (PFL) e o Partido Progressista (PP), dentre outros, e o contrário ocorre com o Partido dos Trabalahadores (PT) - 7,1\% contra $12,2 \%$ do universo total. Isso significa, em primeiro lugar, que o problema das relações entre engajamento associativo e filiação partidária depende do tipo de partido político, aliás, o que foi constatado também para a França do período do governo socialista (GAXIE \& OFFERLÉ, 1985). Em segundo lugar, essa ocorrência também aponta para o fato de que o reforço do capital político "associativo" tende a estar diretamente associado com a expansão do PT, um dos principais aglutinadores, em termos partidários, dos portadores desse tipo de recurso ${ }^{6}$. Além disso, no que tange à troca de partidos, há uma quarta parte $(25,1 \%)$ com apenas uma filiação partidária em seu respectivo trajeto, contra quase a terça parte do universo total $(31,3 \%)$. Os sem vinculação associativa-sindical concentram-se, em termos proporcionais, particularmente, na faixa de cinco filiações $(11,5 \%$ contra $7,4 \%$ do universo total) e naquelas porcentagens mencionadas acima.

\section{OS POLÍTICOS VINCULADOS A ASSOCI- AÇÕES-SINDICATOS DE EMPRESÁRIOS}

Como exemplo da maior parte dos tipos de associação-sindicato, o primeiro dado a destacar relativamente aos vinculados a organizações de empresários é que, em geral, não se trata de mera participação como sócio, mas de dirigentes. Inclusive, há uma proporção maior dos que já exerceram cargos de direção em âmbito nacional na respectiva organização (16,7\% contra $9,1 \%$ do universo total) ou, então, em âmbito estadual (55,3\% contra $24,4 \%$ do universo total), municipal (7,9\% contra $4,1 \%$ do universo total) ou regional (14,9\% contra $6,7 \%$ do universo total). Essas estatísticas indicam que, em geral, a partici-

6 Sobre as relações entre filiação partidária e posição social de elites políticas, ver Gaxie (1980). 
pação em associações-sindicatos de empresários, pelo menos para os que ingressam na política em âmbito nacional, tem um sentido de "carreira" de engajamento e exercício de cargos de direção nesse tipo de organização. Esse sentido, em conjunto com outras modalidades de engajamento, em diferentes formas de combinação, pode compor a base do sucesso de sua reconversão em capital político.

Um aspecto que se destaca nesse caso diz respeito aos recursos econômicos e escolares. Quanto ao patrimônio econômico, há uma forte associação com a faixa mais alta, de US\$1.000. 000,00 ou mais (33,3\% contra $11,5 \%$ do universo total). Além do montante mais elevado, ocorre uma concentração maior dos que possuem determinados investimentos, particularmente, financeiros (77,8\% contra $57 \%$ do universo total).

Como também seria de se esperar, quanto às principais ocupações durante a carreira, os que mantêm vínculos com associações-sindicatos de empresários concentram-se na categoria daqueles cujo trajeto resume-se à administração-propriedade de empresas privadas (15,9\% contra 7,1\% do universo total). Vale salientar também a combinação de administração-propriedade de empresas privadas com a ocupação de cargos públicos de "confiança”. Finalmente, sublinha-se a categoria daqueles cujas ocupações incluem administração-propriedade de empresas privadas, cargos públicos de "confiança” e também cargos públicos eletivos ( $11,5 \%$ contra $4,9 \%$ do universo total).

Relativamente à disciplina-área da graduação universitária, há uma forte associação com cursos de mais aplicabilidade prática no universo empresarial, independentemente da área de conhecimento. Esse é o caso da forte concentração de formados em Administração (10,8\% contra 4,4\% do universo total), nas engenharias e, em menor grau, na Agronomia e na Economia.

É no que tange às relações com o espaço político que esses vinculados a associações-sindicatos de empresários configuram de modo ainda mais nítido uma categoria especial. Isso inclui a filiação partidária, as modalidades de entrada e o conjunto do trajeto político. Quanto à filiação partidária, há uma forte correlação entre vínculos com associações-sindicatos de empresários e orientação política, que se manifesta na concentração em alguns partidos. Além disso, se a quantidade de partidos abrangidos é relativamente grande, todos mantêm orientações políticas muito próximas. A associação mais forte é com o PFL (21\% contra 14,1\% do universo total), seguido do PP (14,3\% contra 4,2\% do universo total), do Partido Liberal (PL) 9,5\% contra 5,3\% do universo total - e, em menor grau, do Partido da Social Democracia Brasileira (PSDB) - 16,2\% contra 14,3\% do universo total). Porém, não ocorre qualquer caso de filiação ao PT, e a proporção de filiados ao Partido Democrático Trabalhista (PDT) - 1,9\% contra 3,6\% do universo total - e ao Partido Socialista Brasileiro (PSB) - 3,8\% contra 5,4\% do universo total) é bem menor.

Nos aspectos que concernem às modalidades de entrada na política eleitoral, ocorre uma forte associação entre posição social e, mais especificamente, estrutura de capital com base em recursos econômicos, incluindo a entrada na política profissional por intermédio de cargos públicos hierarquicamente mais elevados. Além das condições favoráveis de reconversão da condição de empresário em cargos políticos e, portanto, da legitimidade social daquela, isso sugere também que os cargos públicos inferiores são menos atrativos para os empresários. Portanto, ocorre uma seleção anterior às eleições que não exclui apenas aqueles sem condições de concorrer, mas também aqueles cuja posição social torna pouco interessantes cargos como o de Vereador. Os primeiros cargos eleitorais mais diretamente associados são o de vice-Governador (3,7\% contra $0,8 \%$ do universo total) e de Governador, $(0,9 \%$ contra $0,8 \%$ do universo total) embora numericamente pouco significativos, e de Deputado Federal (51,4\% contra $37,7 \%$ do universo total). Todavia, o cargo de Vereador (13,8\% contra $24,6 \%$ do universo total), de vice-Prefeito (1,8\% contra $3 \%$ do universo total) e de Prefeito (8,4\% contra 8,3\% do universo total), ou seja, os mais periféricos, são os menos freqüentes como primeiro cargo eletivo.

Essas condições específicas quanto à entrada na política eleitoral têm efeitos, inclusive, na fase do trajeto social em que isso ocorre. Uma das manifestações desse fenômeno é a entrada na política ou, então, a ocupação do primeiro cargo eletivo em uma faixa de idade bem mais avançada. Assim, uma proporção bem menor dos vinculados a associações-sindicatos de empresários assumiu o primeiro cargo eletivo entre 19 e 30 anos (9,9\% contra $20,5 \%$ do universo total), mas 
uma proporção mais elevada assumiu o primeiro cargo entre 41 e 50 anos e, particularmente, acima de 61 anos (9\% contra 3,1\% do universo total).

Além das relações entre categorias ou modalidades das variáveis tomadas para um tratamento estatístico, é possível um detalhamento maior com base no exame dos trajetos individuais mais representativos dos diferentes padrões ${ }^{7}$. Porém, inicialmente, é necessário destacar que não estão em pauta as relações dos empresários brasileiros com o espaço político, mas do universo formado pelos deputados federais, senadores e ministros de 1994 a 2003. Em outras palavras, trata-se de políticos recrutados com base nas disputas eleitorais, com exceção de alguns ministros que não ocuparam cargos eletivos anteriormente. Embora extrapole os limites do presente trabalho, tudo indica que, particularmente para os empresários do grande capital, as disputas eleitorais não constituem a principal modalidade de ação política. Um dos efeitos desse processo, mesmo sendo o caso de políticos de âmbito nacional, é uma presença mais efetiva de "empresários rurais" ou de representantes da Confederação Nacional da Indústria ou das “pequenas e médias” empresas e não de organizações como, por exemplo, a Federação das Indústrias do Estado de São Paulo (Fiesp).

Seja como for, é possível delinear um conjunto de indivíduos cuja principal base de entrada na política são as atividades associativas-sindicais. Assumindo dimensões numéricas e, portanto, eleitorais, esse tipo de base social não chega a ser muito significativo, pois sempre há um conjunto de esferas de ação. Esse quadro pode ser constituído pela ocupação de cargos públicos de "confiança", pela atuação e por investimentos em organizações associativo-sindicais, pela posse e pelo uso de empresas de comunicação de massa, pelo

\footnotetext{
7 No trabalho do qual foi extraído o material desse texto, foram tomadas algumas dezenas de indivíduos que se posicionam no extremo dos pólos dos primeiros eixos fatoriais, dentre os quais aqueles dos “empresários”, em oposição aos "trabalhadores", que formam o primeiro eixo da análise de correspondência múltipla. Consideraram-se ainda aqueles vinculados a associações-sindicatos de médicos, advogados, engenheiros e assemelhados, que configuram um pólo do segundo eixo, em oposição ao pólo dos “empresários".

8 Na mencionada análise dos cargos de “confiança” como modalidade de entrada na política profissional, foi consta-
}

exercício de alguma outra atividade profissional paralela, em síntese, recursos e atividades com possibilidades de conversão em influência política (BRAUD, 1985) e chances eleitorais.

Embora não seja excludente com relação ao anterior, se depreende um segundo conjunto de indivíduos cuja condição de empresário decorre de um desdobramento daquela de "herdeiro" de um determinado "clã" de "oligarquia regional", com um longo histórico de participação de membros do grupo familiar em atividades políticas. Esse é o padrão que mais se aproxima da hipótese de Badie e Hermet (1983, p. 189-195; BADIE, 1994, p. 191), para os quais, devido a fenômenos como o neopatrimonialismo, as relações entre a acumulação de capital econômico e a ação política no chamado "terceiro mundo" se invertem. Ou seja, nesse caso, é a partir do poder ou da influência política que aumentam as chances de enriquecimento.

Uma outra modalidade de relação com a condição de empresário, que tem efeitos na entrada e na própria carreira política, consiste na utilização de determinada formação profissional em associação com outros recursos. Trata-se de detentores de títulos universitários com forte aplicabilidade prática e valorizados no mercado econômico, como é o caso de certos médicos, advogados, dentre outros.

Além desses diferentes padrões de relacionamento com a condição de empresário e seus efeitos na entrada e no trajeto político, um outro elemento a ser considerado são as modalidades de usos dos vínculos associativo-sindicais na política eleitoral. A entrada e a carreira política podem estar mais diretamente centradas na "organização de interesses” (OFFERLÉ, 1998) empresariais ou, então, de modo mais compósito, incorporar outras bases políticas, socialmente mais ou menos distantes do universo empresarial.

tado que são quantitativamente mais importantes do que os cargos eletivos. Porém, apesar das diferenças e da diversidade de recursos e de princípios de legitimação subjacentes, essas modalidades de exercício de cargos políticos são complementares, não se configurando, portanto, uma oposição mais profunda entre a entrada na política por meio de altos cargos na administração pública e a legitimação pela política eleitoral, como no caso francês (BIRNBAUM, 1994, p. 78 e passim; BOURDIEU, 1989; GARRIGOU, 2001). 
Esses padrões não têm nada de excludente, e o trajeto de um mesmo indivíduo pode incorporar vários deles - em um mesmo momento ou em fases distintas. Um caso exemplar dessa sucessão de esferas de engajamento e militância é o de Marcelo F. Barbieri, que começou com a fase de militância estudantil, passando pelo exercício de cargos de "confiança" para, posteriormente, se concentrar na atuação como líder empresarial. Nesse caso, a entrada na política eleitoral ocorre nessa última fase, mas, em outros, pode acontecer em momentos anteriores, mudando, assim, o peso relativo de cada esfera de atuação no respectivo trajeto político. Outros, como João R. Mendes, apresentam uma entrada na política eleitoral mais diretamente associada a uma carreira de dirigente de associações-sindicatos empresariais em âmbitos estadual ou nacional. Porém, se essa carreira de dirigente de organizações empresariais pode ser decisiva como recurso eleitoral nesse universo, isso não exclui fortes investimentos em filantropia ou, mais especificamente, em organizações de assistência dirigidas à população da periferia urbana.

Como parece evidente, nesse padrão, a atuação em associações-sindicatos de empresários tem um caráter de grupo de interesse, centrada nas relações do universo empresarial com as políticas governamentais. Além desse aspecto, as bases eleitorais dependem da agregação de outras esferas de atuação, por exemplo, a política estudantil, a assistência social, o exercício de cargos de "confiança”, dentre outras. Um outro elemento - geralmente, presente dentro de determinado grau no trajeto da maior parte de políticos empresários - é a respectiva posição nas relações centro-periferia. Esse cenário se manifesta, principalmente, por uma entrada na política eleitoral ocupando, inicialmente, cargos em âmbito local - como o de Prefeito - e, posteriormente, assumindo funções de Deputado Estadual e/ou Deputado Federal. Em muitos casos, anteriormente a esse trajeto político em elevação, também ocorreu uma forte ascensão social, pela acumulação de capital econômico. Evidentemente, esse padrão de entrada na política tem um caráter fortemente privatista e não "militantista" ou politicista 9 . O caso de Roberto Argenta ilustra essa afirmação. Além de ter se

\footnotetext{
9 Sobre as relações entre as empresas sob controle familiar e sua moral específica no que tange à família, à escola, à religião, e à ética política, operando uma espécie de
}

transformado em grande empresário e dirigente de associações-sindicatos de empresários, entrou na política eleitoral como Prefeito de um município do interior do Rio Grande do Sul (Igrejinha). Contudo, mantém fortes vínculos com determinado pólo do catolicismo, sendo, inclusive, um dos fundadores da Partido Humanista da Solidariedade - iniciativa certamente associada ao fato de ter sido seminarista na juventude. O partido é definido como de "inspiração social-cristã", além de apresentar referência étnica de descendência italiana ${ }^{10}$.

Esse caráter não militante e pretensamente apolítico fica ainda mais acentuado no caso daqueles empresários que se tornam ministros encarregados de alguns ministérios tidos como "econômicos”, sem ter exercido qualquer cargo eleitoral e, inclusive, sem filiação partidária. Tal exemplo aplica-se ainda a alguns ministros do governo de Fernando H. Cardoso, como Celso Lafer, não vinculado formalmente à direção de associaçõessindicatos de empresários.Esse é o caso dos ministros do Desenvolvimento, Indústria e Comércio Exterior (Luiz F. Furlan) e da Agricultura, Pecuária e Abastecimento (Roberto Rodrigues), que assumiram em 2003. Apesar de sua imagem de intelectual e de sua carreira de professor universitário, Celso Lafer, além de anteriormente ter exercido o cargo de Ministro das Relações Exteriores, integra um grupo familiar que é proprietário de uma das maiores organizações empresariais do Brasil e com laços de parentesco com diversos dirigentes das principais federações industriais Federação das Indústrias do Estado de São Paulo (Fiesp) e Centro das Indústrias do Estado de São Paulo (Ciesp). Esse exemplo é uma boa indicação de que o universo empresarial e o engajamento em organizações corporativas, a condição de intelectual e a formação de clãs em bases econômicas modernas, nas condições em pauta, podem estar personificadas em um mesmo trajeto social individual ou familiar.

“despolitização”, à medida que tende a remeter os problemas à ordem "pessoal” e do que é "vivido", ver Bourdieu (1989, p. 402). Sobre as lógicas sociais que induzem ao apolítico, particularmente no caso das organizações humanitárias, ver Siméant (2003).

10 Em 2000, foi organizado um Primeiro Encontro de Parlamentares de Origem Italiana, em Roma. Nesse encontro, participaram 35 deputados federais e três senadores brasileiros, entre os quais, o próprio Roberto Argenta. 
Entre os "herdeiros de clãs”, a condição de empresário é decorrente de vínculos prévios com a esfera política. Fernando Bezerra de S. Coelho pode exemplificar essa constatação. De "família tradicional na política”, em Pernambuco, sobrinho de um Deputado Federal, Governador e Senador (Nilo Coelho) e de outro Deputado Federal (Osvaldo Coelho), sua "carreira sempre foi marcada pela participação simultânea em atividades privadas e cargos públicos” (ABREU, 2004). Nessas condições, a gestão das heranças, tanto econômica como política, do grupo familiar se confunde com a atuação "profissional”, em associações-sindicatos empresariais e com o exercício de cargos públicos, de "confiança” ou eletivos. A própria participação em associações-sindicatos de empresários se sobrepõe a outras redes de interesses, político-eleitorais ou de compromissos familiares ${ }^{11}$.

Para entender melhor a situação daqueles que, a partir de determinada herança - incluindo a política -, direcionam-se para o universo empresarial e vice-versa, vale ressaltar, dentre outros, o percurso de Guilherme C. de Melo, que se autoclassifica advogado. Filho de um Senador, neto de um Governador e genro de outro ex-Governador e de uma Deputada Estadual pelo Piauí, também teve um trajeto composto pela ocupação de cargos públicos, atividades empresariais e direção de associações-sindicatos de empresários. Por um período de cerca de 20 anos, foi Presidente da Federação das Indústrias daquele estado e participou da diretoria de uma série de organizações em âmbitos estadual e nacional (como a vice-Presidência da Confederação Nacional da Indústria). Ou seja, as condições de empresário e de dirigente de grupos de interesse empresariais são interdependentes e podem se confundir com aquela de herdeiro político.

Em um primeiro momento, esse padrão teria mais afinidade com a região nordestina e, de fato, pelo menos para o universo em pauta, há uma quantidade maior de "clãs políticos" que, em geral, incorporam atividades em associações-sindicatos de empresários. Isso, no entanto, não significa que não possam ser encontrados casos muito semelhantes na maior parte dos estados ou re-

\footnotetext{
11 Sobre a influência das relações de parentesco e de amizade nas relações de empresários com o Estado e seus efeitos na corrupção, ver Bezerra (1999, p. 231-254).
}

giões brasileiras. Santa Catarina, quase no outro extremo geográfico, expõe essa semelhança por meio de Jorge Konder Bornhausen. Filho de um banqueiro e político que foi um dos fundadores da antiga União Democrática Nacional (UDN), sobrinho de um Deputado Federal e Governador do estado, o poder político do clã no local remonta a década de 1920 do século passado. Apesar da tentativa dos comandantes da Revolução de Trinta para afastá-los do poder político apoiando o clã rival (os Ramos), os Konder Bornhausen recuperaram sua importância (ABREU, 2004). O próprio Jorge K. Bornhausen, após um período como advogado e diretor de empresas do grupo familiar, aos 29 anos “ingressou na política pela mão do pai”, ao ser indicado, durante o regime militar, para ser Governador. Posteriormente, passou a exercer outros cargos, eletivos e de "confiança", como aqueles de Ministro, de Embaixador e de Senador, enquanto parentes próximos das novas gerações ingressavam na política eleitoral.

Quanto àqueles cuja condição de empresário está vinculada a determinadas profissões, a classificação profissional insere-se em uma posição social de origem que, além de títulos escolares valorizados, inclui a herança de capital econômico considerável, com investimentos em diversos setores. O título profissional, como o de médico, por mais importante que possa ser em termos simbólicos ou para a legitimação do exercício de cargos públicos de "confiança”, é completamente secundário para a definição do conjunto dos recursos e da posição social e, em muitos casos, para a entrada na política eleitoral. Se, para alguns, mais do que a classificação e o título escolar, a principal base da respectiva posição social está nos investimentos econômicos diversificados, em outros casos, ocorre uma relativa especialização no setor ou ramo da própria profissão. Esse é o caso da vinculação do título ou da condição de médico com aquela de empresário, por meio da transformação da Medicina em empresa econômica. No caso de médicos, normalmente, esse processo ocorre com a posse e o controle dos aparatos técnico e organizacional necessários, como clínicas e hospitais.

Ronaldo Caiado, dentre outros, é um caso expositivo daqueles cujo título de médico consiste em apenas um componente a mais de uma posição social e politicamente dominante e, simultaneamente, um dos representantes dos grandes proprietários rurais. De modo semelhante, Fran- 
cisco G. Rodrigues, apesar de se autoclassificar médico e empresário, tem todo o trajeto profissional composto pela administração e participação na propriedade de uma série de empresas econômicas de diferentes setores, além do exercício de cargos públicos de "confiança” e eletivos e de representação associativa-sindica. O título de médico de Inocêncio G. de Oliveira também é um mero complemento daquele de empresário, com a diferença de que a posse e a administração de hospitais, como empresa econômica, foi central na fase inicial de seu trajeto. Após uma longa carreira política - e da expansão do patrimônio econômico , a condição de empresário passou a incluir grandes propriedades rurais, concessionárias de automóveis, estações de rádio e de televisão, com um patrimônio calculado em mais de US\$ 5000 000,00 em 1997. Esse padrão inclui muitos outros exemplos, como Jorge Maluly Neto, com o acréscimo, nesse caso, do peso das referências étnicas como recurso eleitoral e, também, do exercício de cargos de "confiança" vinculados ao controle do exercício médico em prefeituras do interior.

Para tomar um caso exemplar dessas relações entre a condição de empresário e outras profissões que não a Medicina e, mais especificamente, com a Engenharia, pode ser incluído o nome de Jaime Martins Filho, apesar de se classificar como advogado, engenheiro e empresário. Aliás, as classificações "profissionais" múltiplas consistem em uma das características mais comuns desse tipo de político, o que decorre da multiplicidade de esferas de atuação nas quais inserem-se os títulos escolares e "profissionais". Filho de ex-Deputado Estadual, em seu trajeto profissional, passou cerca de 20 anos em cargos de diretoria em diversas empresas siderúrgicas e de energia elétrica. Adicionalmente, foi pecuarista e passou um pequeno período como professor de Engenharia. Em termos de engajamento associativo, chegou a ser tesoureiro do Sindicato do Ferro em âmbito estadual, sendo um dos autores do Programa Nacional de Ferro-Gusa (1989), e de uma publicação sobre economia empresarial, além de sócio de uma série de organizações de produtores rurais e conselheiro de um clube de futebol profissional. Como se pode ver, por se tratar de Engenharia, a exemplo de outros casos que poderiam ser apresentados, as relações entre a condição "profissional” e aquela de empresário tendem a envolver grandes empresas. No entanto, as relações com as organizações empresariais e com o universo da política não diferem muito dos padrões apresentados acima, visto que é a condição de empresário, ou seja, de gestor de recursos e relações sociais, que se impõe.

Por fim, nessas relações entre o universo empresarial e a modalidade de entrada e carreira política, cabem alguns casos de empresários rurais que têm como um dos aspectos que mais se destacam a não exclusividade e, em muitos casos, a situação secundária das atividades e/ou investimentos estritamente "rurais" ou agropecuários. Via de regra, trata-se de investimentos multissetoriais, que incluem, em diferentes graus, a produção primária.

Um outro aspecto sobressalente desses políticos considerados "líderes ruralistas" é que a atuação associativa-sindica está mais diretamente baseada em "movimentos" e em modalidades de mobilização e ação coletiva paralelas, embora não excludentes - e até complementares - ao sindicalismo rural patronal. Esse é o caso, por exemplo, da União Democrática Ruralista (UDR), das freqüentes "marchas", dos "tratoraços", dos "boicotes" ou algo semelhante. Acrescenta-se a esse quadro a importância de modalidades de pressão política como as "frentes parlamentares", no caso, a "bancada ruralista” ou Frente Parlamentar da Agricultura, embora isso não seja uma exclusividade daqueles ${ }^{12}$. Um outro aspecto que se destaca é que a maior parte desses políticos "líderes ruralistas" é herdeira de "clãs" de "oligarquias" regionais há muitas gerações atuando na política e, portanto, não se trata de alguma nova categoria rural socialmente dominante. Evidentemente, esse fato não exclui "novos entrantes" na condição de grande proprietário rural e de político, em setores e situações específicas.

Alguns dos casos exemplares desses políticos “líderes ruralistas” e herdeiros de clãs de oligarquias políticas são, inclusive, aqueles mais divulgados pela imprensa, como Abelardo L. Lupion Mello, Ronaldo R. Caiado, dentre outros. O primeiro, Abelardo L. Lupion Mello, que se classifica como agropecuarista e empresário, é filho de um também empresário paranaense, eleito duas vezes Governador do Estado. Além disso, foi um

12 Para mais detalhes sobre a composição da Frente Parlamentar da Agricultura ou "bancada ruralista”, além dos próprios arquivos da Câmara dos Deputados, ver Vigna (2001). 
dos principais protagonistas nos conflitos fundiários no Oeste daquele estado, nas décadas de 1940 e 1950, com muitos choques armados com “colonos” ou pequenos proprietários imigrantes, dos quais resultaram muitas mortes ${ }^{13}$. Em todo caso, de todos esses conflitos e apropriação fundiária, descritos na auto-apresentação como “pioneirismo", resultou aquilo que é definido pelos próprios representantes como "o maior grupo empresarial paranaense, um dos maiores do Brasil”, com base, inicialmente, na exploração de madeira (ABREU et al., 2004). De qualquer modo, trata-se de um "ruralismo" que, pelo menos quanto a seus representantes associativos e políticos, não está diretamente associado a algo que possa ser definido como economicamente "tradicional" ou "improdutivo".

Ainda mais associado a alguns indicadores de “modernidade” e com alta titulação escolar (diferentemente de Abelardo L. P. Mello, que conta apenas com curso superior incompleto), destacase Ronaldo R. Caiado, que se autoclassifica como médico, professor e produtor rural. Natural do interior de Goiás, é neto de um ex-Deputado Federal e Senador no início do século XX e "um dos mais temidos coronéis de Goiás, liderando a oligarquia Caiado entre 1910 e 1930, deposta [...] por Getúlio Vargas. Seu tio, Brasil Ramos Caiado, foi Presidente do estado de 1925 a 1929 e Senador entre 1929 e 1930. Mário [...] Caiado integrou a junta governativa que assumiu o poder em Goiás com a Revolução de 1930, tendo sido ainda constituinte em 1934 e Senador de 1935 a 1937. No mínimo, cinco de seus primos foram políticos” (ABREU et al., 2004). Origens sociais assim podem parecer completamente em desacordo com a procura pelo curso e pela profissão de Medicina, apesar de haver vários médicos na família, ou melhor, médicos políticos. Porém, além do curso na Universidade Federal do Rio de Janeiro, realizou uma série de estágios, tanto nessa cidade como em Paris. Teve, inclusive, uma publicação sobre Medicina editada na capital francesa, apesar de seu breve período de exercício profissional no local. Embora mais centrado na condição de "pecuarista”, o trajeto de Jaime Fernandes Filho, para mencionar apenas mais um caso expositivo, não se distancia dos expostos acima.

13 Sobre esses conflitos fundiários, ver o estudo de Forewaker (1982).
Apesar de seu título escolar mais alto ser o de técnico em Agropecuária, seu trajeto de engajamento associativo circunscreve-se nas organizações de representação de interesses da pecuária em âmbito estadual. Seu capital de relações sociais - e, mais especificamente, de parentesco e de influência política - inclui o casamento com a filha de ex-Presidente do Banco do Brasil e do Banco Econômico (Ângelo C. de Sá). Portanto, como mencionado, a exemplo da maior parte desses políticos considerados "líderes ruralista”, os vínculos com a produção agrícola são apenas um componente - em geral, secundário - da posição social e do conjunto de atividades "profissionais" e de representação de interesses.

Um último padrão de associação entre a condição de empresário rural e ação política, menos dependente de origens sociais altas, está mais centrado no chamado "poder local”, ou no exercício de cargos de Vereador e de Prefeito, para posteriormente ser eleito Deputado Federal. Como um dos casos exemplares, pode ser tomado Nelson Meurer, que se autoclassifica simplesmente como pecuarista. Natural do interior de Santa Catarina, teve trajeto de produtor rural e político baseado em Francisco Beltrão (PR), onde foi Presidente do Sindicato Rural Patronal em âmbito municipal. Começou a carreira como Prefeito, além de ser o Presidente de uma cooperativa de eletrificação rural. Posteriormente, foi eleito Deputado Federal por diversos mandatos, mudando várias vezes de partido, todos politicamente próximos (Arena, PPR, PPB).

\section{OS POLÍTICOS VINCULADOS A ASSOCI- AÇÕES-SINDICATOS DE TRABALHADO- RES URBANOS, RURAIS E DE FUNCIONÁ- RIOS PÚBLICOS}

Os políticos que mantêm algum tipo de vínculo com associações-sindicatos de trabalhadores (104 indivíduos, ou 11,5\% do universo total) configuram a categoria que pode ser tomada como a mais diretamente oposta àquela formada pelos vinculados a associações-sindicatos de empresários. Dentre as características ou indicadores mais específicos, destacam-se as modalidades de inserção profissional, de escolarização, de filiação partidária e de entrada e subseqüente carreira política.

Antes de apresentar estas características específicas, no entanto, cabe qualificar o tipo de vinculação predominante com associações-sindi- 
catos. Seguindo o exemplo de outras categorias, trata-se de dirigentes e não de meros sócios. Ou seja, há uma forte associação entre a condição de político eleito em âmbito nacional, que compõe o universo em pauta, e a ocupação de cargos de direção em diferentes níveis, nas respectivas organizações. O tipo de cargo mais freqüentemente ocupado é o de dirigente em âmbito estadual, exercido por quase metade $(48,6 \%$ contra $24,4 \%$ do universo total), seguido de perto pelos que ocuparam cargos de direção em âmbito nacional (22,9\% contra $9,1 \%$ do universo total) ou regional ( $17,1 \%$ contra $6,7 \%$ do universo total). A ocupação de cargos de direção em âmbito municipal é menos freqüente, embora em uma proporção acima da média $(5,7 \%$ contra $4,1 \%$ do universo total). No entanto, há uma quantidade insignificante dos que são apenas membros ou sócios (4,8\% contra $4,2 \%$ do universo total).

Relativamente às principais ocupações na carreira, a primeira modalidade associada com mais intensidade é constituída por aqueles cujo trajeto é composto pela condição de empregado ou funcionário de empresas privadas com o exercício de cargos de direção de organizações sindicais (22,2\% contra 2,6\% do universo total). A segunda modalidade, pela ordem de importância, é aquela cujo trajeto é formado pela composição, simultânea ou sucessiva, de serviço ou administração pública com a ocupação de cargos públicos de "confiança” (21,3\% contra 12,9\% do universo total). A terceira modalidade é composta por um grupo cujo trajeto é formado pela condição de servidor público com a ocupação de cargos de direção sindical (14,8\% contra 2,5\% do universo total). Há outras modalidades com alguma importância, como aquela em que o trajeto é formado pela condição de funcionário de organizações e/ ou empresas privadas com a ocupação, simultânea ou sucessiva, de cargos públicos de "confiança” e/ou eletivos (4,6\% contra 2,2\% do universo total).

No que tange à área do título de graduação universitária, ressalta-se a associação mais forte com as chamadas Ciências Humanas (Ciências Sociais, Pedagogia, Letras, Filosofia, Teologia, História e Serviço Social, com 13,2\% contra 8,7\% do universo total) e com os sem título universitário ou com curso superior incompleto $(27,4 \%$ contra $14,7 \%$ do universo total). Entretanto, não há qualquer ocorrência de formados em Agronomia, uma proporção bem menor de formados em
Direito (20,8\% contra 29,8\% do universo total), em Economia (2,8\% contra 6,8\% do universo total) e em Medicina (4,7\% contra $12,9 \%$ do universo total).

Como seria de se esperar, há uma forte correlação com o montante do patrimônio, apesar da incidência de somente dois casos dos sem patrimônio ou com até US\$ 10 000,00. As maiores concentrações ocorrem nas faixas de US\$ 10 000,00 a US\$ 50 000,00 (14,7\% contra 6,9\% do universo total) e naquela entre US\$50 000,00 e US\$ 100 000,00 (10,1\% contra 4,2\% do universo total), em detrimento de todas as mais elevadas, particularmente naquela de US\$ 1000 000,00 ou mais (2,8\% contra $11,5 \%$ do universo total).

Quanto às relações com o universo político, as características próprias abrangem tanto a filiação partidária como as modalidades de entrada e de trajeto político. Relativamente à filiação partidária, um dos aspectos que se salienta é a forte concentração em apenas um partido (PT) e a continuidade da adesão, indicada no confronto entre a primeira e a última filiações e o número de alterações no decorrer do trajeto. Nada menos do que $57,7 \%$ contra $18,2 \%$ do universo total tem o PT como a última filiação partidária. Além dele, apenas o PSB (5,8\% contra 5,4\% do universo total) e o conjunto de pequenos partidos quantitativamente pouco significativos (1,9\% contra $1,4 \%$ do universo total) contam com uma proporção ligeiramente superior daqueles que apresentam vínculo com associações-sindicatos de trabalhadores urbanos, rurais e de funcionários públicos. Todavia, alguns partidos, como o PPS, não contam com qualquer filiação daqueles; e outros apresentam pouquíssimos casos (PP, com dois indivíduos, e o PDT, também com apenas dois). Nesse caso, ao comparar a última filiação partidária com a primeira, os resultados são praticamente os mesmos. Além disso, há uma alta proporção dos que têm o PT como primeira filiação partidária. Conseqüentemente, a maior parte teve apenas uma filiação partidária (65,7\% contra $31,3 \%$ do universo total), e o restante se concentra na faixa de duas filiações (18,52\% contra 22,6\% do universo total).

Além dos cargos nas próprias organizações associativas ou sindicais, os vinculados a esse tipo de organização destacam-se também pela ocupação de cargos de direção em partidos políticos. Assim, vale salientar a participação como mem- 
bro de diretório ou comissão executiva estadual e o exercício de cargos de direção, e não apenas como membro de diretório ou comissão executiva estadual ou regional.

Nesse contexto, ficam evidentes os efeitos de uma situação própria no ciclo de vida relativamente à carreira política. Eles manifestam-se de diferentes formas: uma delas refere-se à idade, comparativamente ao conjunto do universo e, mais ain$\mathrm{da}$, frente àqueles vinculados a associações-sindicatos de empresários. Para os que mantêm vínculos com associações-sindicatos de trabalhadores urbanos, rurais e de funcionários públicos, por um lado, a faixa etária mais diretamente associada é de 41 a 50 anos em 2000 (55\% contra 35,7\% do universo total), seguida pela de 31 a 40 anos (17,4\% contra $12,6 \%$ do universo total). Por outro, significativamente, além de uma menor proporção nas faixas etárias mais elevadas, como a de mais de 60 anos $(6,4 \%$ contra $14,5 \%$ do universo total) e naquela de 51 a 60 anos $(21,1 \%$ contra 34,8\% do universo total), não há nenhuma ocorrência com menos de 20 anos, embora essa faixa etária seja significativa para o conjunto do universo. Esses dados permitem diferentes interpretações. A mais plausível é a de que a oferta de condições de engajamento e militância no período anterior dificultava o ingresso na política profissional. Tal interpretação pode abranger tanto o engajamento associativo ou sindical como sua “politização” (LAGROYE, 2003) ou reconversão em atuação político-eleitoral. Visto sob uma ótica complementar, o cenário sugere que os indivíduos provenientes desse tipo de sindicalismo, por seus recursos frente às condições de competição político-eleitoral, mantêm uma taxa de sobrevivência menor como políticos, com um número reduzido de cargos eletivos. Essa suposição, no entanto, teria de ser especificada por um exame de cada caso, cujas informações disponíveis nem sempre permitem um detalhamento mais apurado.

Esse "efeito geração" transparece também no número bem menor de mandatos eletivos já exercidos. A faixa mais diretamente associada é a de apenas um mandato (30,6\% contra $16,6 \%$ do universo total), seguida pela de dois e pela de três mandatos. Há, porém, somente dois casos com o exercício de oito ou mais mandatos, embora essa ocorrência seja significativa para o conjunto do universo (5,6\%). Algo semelhante ocorre em todas as faixas de mais de seis mandatos.
Por fim, no que tange à "entrada na política" ou ao primeiro cargo eletivo, nota-se uma concentração maior no cargo de Deputado Federal (51,5\% contra $37,7 \%$ do universo total), em detrimento do cargo de Deputado Estadual. Isso evidencia que, a exemplo dos vinculados a associações-sindicatos de empresários, são portadores de recursos políticos mais “centrais”, ou, no mínimo, com menos afinidades ao exercício de cargos em âmbito "local”.

No que tange aos representantes de categorias de operários e de funcionários do setor de serviços, o aspecto mais geral que se sobressai é a associação muito direta com alguns ramos específicos da economia. Isso poderia suscitar, inclusive, discussões normativas sobre a "representatividade" sindical ou política das diferentes condições de classe ou categorias profissionais ${ }^{14}$. O que está em pauta, no entanto, circunscreve-se aos problemas analíticos das relações entre o engajamento e a militância sindicais e o recrutamento de elites políticas.

No caso estudado, a categoria dos operários é composta, principalmente, por empregados metalúrgicos e aquela dos funcionários do setor de serviços. Esta última consiste, basicamente, em

14 Para uma comparação entre a bibliografia francesa e a norte-americana e a possibilidade da associação com um certo normativismo na utilização de indicadores sociográficos em detrimento de variáveis de cunho político, ver Sawicki (1999).

No mencionado trabalho, do qual foi extraído o material deste texto, utilizando as sugestões de Gaxie (1980) e os dados da Pesquisa Nacional por Amostra de Domicílios de 2002 (IBGE, 2003), foi calculado o Índice de Representação Política, além do grau de sindicalização, para os diferentes agrupamentos ocupacionais. Quanto ao Índice de Representação Política, destacam-se, em primeiro lugar, os classificados como profissionais das ciências e das artes, seguidos pelos dirigentes em geral. Além desses agrupamentos, apenas um conjunto de ocupações mal definidas apresenta um alto índice de representação política. Do restante, somente os militares revelam um índice significativo. Quanto aos técnicos de nível médio e aos trabalhadores de diferentes setores, esse índice é muito baixo, e, no caso específico dos trabalhadores de serviços, vendedores e prestadores de serviços do comércio, quase nulo. Esse baixo índice de representação política, no entanto, não significa que não possa haver uma quantidade considerável de políticos originários de algumas dessas categorias ocupacionais, na medida em que ela abarca uma quantidade maior da população economicamente ativa, como é o caso, por exemplo, dos trabalhadores dos serviços. 
bancários e empregados de grandes empresas, boa parte das quais de controle estatal ou misto. Porém, esses aspectos estão longe de esgotar as condições concretas e as práticas de engajamento e militância e seus efeitos na entrada para a política eleitoral. Nesse sentido, devem ser incorporados na análise pelo menos três outros condicionantes: as interações com outras esferas de militância, com graus variáveis de afinidade com a atuação sindical; as respectivas tomadas de posição nas lutas de concorrência no universo de representação sindical e frente às centrais; e, por fim, as respectivas posições nas relações centro-periferia. Em todo caso, como parcela significativa de representantes dos sindicalistas "operários" nesse pólo dos "trabalhadores", podem ser tomados indivíduos como Miguel S. Rossetto, Vicente P. da Silva, Antonio L. O. de Oliveira, Luiz S. N. de Oliveira e Manoel do Carlo Vitório.

O primeiro, M. Rossetto, pode ser tomado como caso exemplar, inclusive, de reconversão bem-sucedida de militância sindical em capital político, em determinadas condições. Tendo começado a carreira profissional como técnico em mecânica e de militante sindical em sua cidade de origem (São Leopoldo), posteriormente passou a ser empregado de uma grande empresa de petroquímica na região metropolitana de Porto Alegre. Conjuntamente a uma intensa carreira de militante e de dirigente sindical, concluiu o curso de Ciências Sociais e passou a disputar cargos políticos eletivos. Para outros, como Antonio L. O. de Oliveira - de origem mais periférica e com menos capital escolar, além da militância sindical -, as demais esferas de militância estão mais diretamente vinculadas com associações de moradores da periferia urbana. Contudo, dentre os trajetos de militante sindical mais bem-sucedidos no universo em pauta, figura o de Vicente P. da Silva. No caso dele, o peso das origens sociais periféricas (filho de pequeno agricultor no interior do Rio Grande do Norte) está mais diretamente presente na fase prévia da carreira de militante sindical, antes da imigração e do ingresso na carreira de metalúrgico. Isso porque, apesar dessas origens, a posição central da categoria representada favorece a ocupação de cargos nas instâncias sindicais mais amplas, como a Central Única dos Trabalhadores (CUT). Mesmo assim, a carreira militante começou anteriormente à imigração, em grupos de jovens da Igreja Católica (ABREU et al., 2004).

Quanto aos “funcionários”, como já mencio- nado, alguns dos casos exemplares são personificados por Olívio de O. Dutra, Joaquim A. C. de Brito, Pedro Celso, dentre outros. O primeiro, de origens sociais extremamente periféricas, após uma carreira de funcionário de banco estadual e de dirigente sindical, além da militância e exercício de cargos de direção partidária em âmbitos estadual e nacional, passou a disputar e a exercer cargos políticos eletivos. De modo semelhante, Joaquim A. C. de Brito, embora menos bem-sucedido na carreira política, concomitantemente à condição de empregado de empresa estadual de energia, teve uma longa carreira de militante sindical em âmbito estadual. Além disso, essas militâncias sindical e partidária são articuladas com a atuação e a liderança no mencionado Movimento Evangélico Progressista. Por sua vez, Pedro Celso, também proveniente de origens sociais humildes, tem um trajeto de militância e direção sindical dos empregados de empresas de transporte e, a exemplo dos demais, na CUT nacional, além da militância partidária.

Por fim, para mencionar sinteticamente alguns casos exemplares de representantes de trabalhadores rurais, o primeiro aspecto que se destaca é a enorme distância quanto às origens e à posição social relativamente aos demais "trabalhadores". Essas fortes diferenças quanto às condições sociais de origem desses líderes, e de existência das categorias representadas frente ao conjunto do sindicalismo e da militância associativa, aliás, são bons indicadores da eficácia do sindicalismo e da militância associativa. Nesse aspecto, eles criam redes e sistemas de ação, ou seja, um "conjunto de agrupamentos e de associações os quais contribuem cada um à sua maneira e conforme suas lógicas de funcionamento próprias, para a construção de um grupo de referência” (LAGROYE, FRANÇOIS \& SAWICKI, 2002, p. 271), que extrapolam, pelo menos, algumas das condições particulares de existência das respectivas categorias representadas.

Entretanto, tais trajetos podem ser tomados também como exemplares quanto ao engajamento múltiplo e, inclusive, das ambivalências da representação classista daquilo que passou a compor a categoria dos "trabalhadores rurais" 15 . Como um caso ilustrativo desse tipo de político oriundo do

15 Sobre as ambivalências na utilização de categorias como aquela de "trabalhador rural" nas mobilizações e lutas sindicais, ver Coradini (1996). 
sindicalismo e dos movimentos de trabalhadores rurais, pode ser tomado o Deputado Adão Pretto. Após um período de militância nas Comunidades Eclesiais de Base (CEBs) da Igreja Católica e Movimento dos Trabalhadores Rurais Sem Terra (MST) no interior do Rio Grande do Sul, além da CUT estadual, se engajou no PT, pelo qual foi eleito para diversos cargos. Como Deputado, sempre manteve uma forte vinculação com essas organizações e movimentos e, na Câmara dos Deputados, com a atuação em comissões como a de Agricultura e Política Rural.

Já Valdir Ganzer, embora representante do Pará, é oriundo da mesma região do interior do Rio Grande do Sul de Adão Pretto (Alto Uruguai). Sua família, de origem de "pequenos proprietários”, transferiu-se para a área da Transamazônica na década de 1970 . Seu irmão, inclusive, apresentou um trajeto muito semelhante, que abrange este tipo de engajamento, pois foi fundador e dirigente nacional da CUT, com engajamento na Pastoral da Juventude da Igreja Católica e na militância sindical, além do exercício de cargos de direção partidária. Seu mandato de Deputado Federal, segundo o próprio Ganzer, seria exercido “de forma articulada com as organizações do movimento social”. Ou seja, nesse padrão, fortemente associado às militâncias associativa e sindical, apesar daquela também partidária, tanto a candidatura como o cargo são apresentados como algo a serviço do sindicalismo ou, de modo mais amplo, de um conjunto de "movimentos sociais". Por fim, para tomar apenas um caso de outra região, mas muito semelhante, José G. T. da Silva, apesar de também ser Deputado pelo Pará, é oriundo do interior do Espírito Santo. No entanto, a exemplo de Valdir Ganzer, sua família, originada de "lavradores”, deslocou-se para a região da Transamazônica na década de 1970. Após uma carreira de dirigente sindical local e de ter sido coordenador do Movimento pela Sobrevivência da Transamazônica nas décadas de 1980 e 1990, ingressou na militância partidária, tendo sido um dos fundadores do PT em âmbito local.

\section{OS POLÍTICOS VINCULADOS AASSOCIA- ÇÕES-SINDICATOS DE PROFESSORES}

Os políticos vinculados a associações-sindicatos de professores - de $1^{\circ}$, $2^{\circ}$ e $3^{\circ}$ graus - tomados em conjunto (31 indivíduos, equivalente a $3,1 \%$ do universo total), apesar de uma série de características muito próprias, ocupam uma po- sição muito próxima daqueles vinculados a associações-sindicatos de trabalhadores urbanos, rurais e de funcionários públicos. Contudo, visando a uma melhor especificação de algumas condições próprias, no tratamento estatístico, foram tomados separadamente.

De modo semelhante a outras categorias, em geral, não se trata de meros sócios ou participantes desse tipo de organização. Praticamente a totalidade (com exceção de apenas dois casos que são apenas membros) ocupa, ou ocupou, funções de direção na respectiva organização. A maior concentração ocorre nos cargos de direção em âmbito estadual, que abrange mais da metade (56,7\% contra $24,4 \%$ do universo total), seguidos pelos cargos de direção em organizações não hierarquizadas territorialmente (20\% contra 5,8\% do universo total) e, por fim, cargos de direção em âmbito nacional.

Quanto às ocupações durante a carreira, a categoria mais diretamente associada é aquela que descreve um trajeto composto pelo exercício do magistério secundário em combinação com a ocupação de cargos públicos de "confiança” e/ou eletivos, abrangendo mais de uma terça parte (37,5\% contra $3,3 \%$ do universo total). A segunda maior associação é com a categoria cujo trajeto consiste na combinação do exercício do magistério universitário com a ocupação de cargos públicos de "confiança" e/ou eletivos (40\% contra 7,8\% do universo total). Além dessas, apenas a categoria cujo trajeto consiste na combinação da condição de funcionário ou administrador público com a de dirigente sindical tem uma participação significativa $(9,4 \%$ contra $2,5 \%$ do universo total). Portanto, no caso dos professores, as duas principais modalidades de entrada na política profissional ocorrem na reconversão do militantismo associativo-sindical em recurso para a ocupação de cargos públicos de "confiança” ou eletivos e da notabilidade decorrente do exercício de cargos de "confiança" em recurso eleitoral.

Como se trata de vínculos com associaçõessindicatos de professores, apesar de todos os níveis tomados em conjunto, a exemplo de outras categorias diretamente dependentes da titulação escolar, nesse caso, também há uma forte associação com determinadas áreas no curso de graduação universitária. Dessa maneira, não existe qualquer caso sem escolarização universitária (contra $14,7 \%$ do universo total) e apenas um caso com 
curso superior incompleto. A associação mais forte ocorre com o conjunto formado pelas chamadas Ciências Humanas e Sociais, que contempla mais de uma terça parte $(34,4 \%$ contra $8,8 \%$ do universo total). A segunda delas vincula-se a um conjunto de disciplinas heterogêneas, abrangendo mais de uma quarta parte ( $25 \%$ contra $14,7 \%$ do universo total). Na maior parte dos casos, trata-se de cursos menos "tradicionais" e com reduzida valorização social. Em terceiro lugar, com uma participação quantitativamente bem menos significativa, aparece a Medicina como área de graduação universitária. O restante divide-se entre Economia e Direito, mas, embora quantitativamente muito significativo, em uma proporção inversa (9,4\% contra $29,8 \%$ do universo total formado em Direito), a exemplo das Engenharias (com apenas um caso ou $3,1 \%$ contra $10,2 \%$ do universo total). Visto que a distribuição por disciplinas está diretamente associada com a divisão sexual, e as mulheres aproximam-se mais das chamadas Ciências Humanas, os vinculados a associações-sindicatos de professores constituem a única categoria com uma proporção significativa do sexo feminino, atingindo uma terça parte (31,3\% contra 6,2\% do universo total). Em síntese, fica evidente uma forte correlação entre o tipo e a importância social e econômica do título universitário e a distribuição entre as associações de empresários ou, por um lado, de médicos, advogados, engenheiros e assemelhados e, por outro, de professores. Porém, se essa máxima vale para o tipo de curso, o inverso ocorre com o grau de titulação. Além da titulação escolar, em geral, mais alta, embora em uma proporção menor do que os vinculados a associações-sindicatos de médicos, advogados, engenheiros e assemelhados, uma quantidade bem acima da média dos filiados em associações-sindicatos de professores tem algum curso de pós-graduação, seja de mestrado (18,5\% contra 5,2\% do universo total), de doutorado ( $11,2 \%$ contra $4,3 \%$ do universo total), ou de especialização (30,8\% contra $18,0 \%$ do universo total).

No que tange ao patrimônio, as faixas de maior concentração podem ser consideradas como médias ou baixas, a começar pela de US\$ 10 000,00 a US\$ 50 000,00 (19,4\% contra 6,9\% do universo total), seguida pela de US\$ 50000,00 a US\$ 100 000,00 (19,4\% contra 4,2\% do universo total), o que não é o caso da faixa de
US\$ 100 000,00 a US\$ 500 000,00, que abrange uma parte relativamente significativa, embora em menor proporção do que o conjunto do universo (12,9\% contra $22,5 \%$ do universo total). Nesse caso, no entanto, é necessário considerar que as informações relativas ao patrimônio não são exaustivas e, para aqueles vinculados a associações-sindicatos de professores, os sem informações chegam a $42,7 \%$. Mas, além do montante do patrimônio, o vinculados a associações-sindicatos de professores caracterizam-se também pela menor proporção dos que mantêm determinados investimentos, particularmente, financeiros. Três quartos contra menos da metade do universo total (75\% contra 43\%) dos com informações disponíveis não têm qualquer investimento financeiro.

Os indicadores que destacam mais fortemente os vinculados a associações-sindicatos de professores, porém, são aqueles relativos ao trajeto político e, dentre estes, a filiação partidária. Se, no caso dos vinculados a associações-sindicatos de empresários ocorre uma certa concentração em alguns partidos (particularmente o PFL e o PPB) e dos vinculados a associações-sindicatos de médicos, advogados, engenheiros e assemelhados, há uma dispersão que não resulta em associações mais efetivas (pequena concentração no PDT, no PPS, no PSB e no conjunto de pequenos partidos), a forte vinculação a associações-sindicatos de professores é com o PT, que abrange mais de quatro quintos das filiações (82,1\% dos filiados a associações-sindicatos de professores contra apenas $18,2 \%$ do universo total). Esse partido é o único ao qual os vinculados a associações-sindicatos de professores, de todos os níveis, mantêm uma proporção maior de adesão. Do restante, em uma dimensão bem menor, uma parte é filiada ao PSDB (10,4\% contra $14,1 \%$ do universo total) e ao PMDB (com apenas dois casos). Os demais partidos não contam com qualquer ocorrência de filiação (tomando-se a última) dos vinculados a associações-sindicatos de professores. Essa observação tem efeitos diretos no número de filiações partidárias, visto que, como já indicado, os filiados ao PT são os que menos mudam de partido. Desse modo, bem mais da metade $(67,7 \%)$ dos vinculados a associações-sindicatos de professores teve uma única filiação partidária, contra menos de um terço (31,3\%) do universo total. Quase todo o restante dos vinculados a associações-sindicatos de professores, com exceção de apenas dois 
indivíduos, teve duas filiações (25,8\% contra $22,6 \%$ do universo total com duas filiações).

Além dessa forte concentração em apenas um partido, há também uma associação intensa com o exercício de cargos de direção partidária. O cargo mais diretamente associado é o de membro de diretório ou comissão executiva estadual, e mais de uma quinta parte $(22,6 \%$ contra $4,9 \%$ do universo total) ocupa ou já ocupou esse tipo de função. Em seguida, vêm os cargos de direção em diretório ou comissão executiva nacional, com mais de um terço, embora isso signifique uma proporção menor do que o conjunto do universo (32,3\% contra $49,8 \%$ do universo total). Finalmente, surge uma quantidade ainda mais reduzida: a participação como membro de diretório ou comissão executiva em âmbito regional (12,9\% contra 3,6\% do universo total), ou em outros níveis. Portanto, de acordo com a participação em associações-sindicatos, relativamente aos partidos, também não se trata de meros aderentes, o que indica que esses sindicalistas bem-sucedidos na carreira política caracterizam-se, inclusive, pela intensa militância partidária.

As variações nas modalidades de se relacionar com a "profissão", com sua representação sindical ou corporativa, com outras modalidades de militância e, conseqüentemente, com a própria entrada e carreira política são extremamente amplas, o que não impede o estabelecimento de alguns padrões. No caso dos professores, estes padrões são condicionados, principalmente, pelo tempo dedicado à ocupação no magistério stricto sensu, à representação sindical ou a outras modalidades de militância, à ocupação de cargos de “confiança” e, por fim, à conquista e exercício de cargos eletivos.

Apesar das variações individuais, sempre há diferentes modalidades de combinação dos recursos de origem e posição social com a condição profissional e a militância sindical e/ou associativa na entrada e no trajeto político. Como se trata de políticos vinculados ao sindicalismo, a profissão é central como categoria de referência. Porém, tanto essa referência à categoria profissional de origem como a outras mais somente toma sentido no conjunto das esferas de engajamento. Em geral, apesar da forte "multiposicionalidade" desse engajamento, que inclui sindicalismo, associações apoiadas por igrejas e outros movimentos sociais, há possibilidade de formarem-se interseções com base em afinidades entre pólos específicos das esferas de atuação que atravessam seu conjunto. Essa tendência, no entanto, é variável para cada pólo tomado isoladamente e, no caso desse dos "trabalhadores", é necessário considerar que na passagem dessa representação associativa-sindica para a política eleitoral, o partido ao qual a maior parte é filiada (PT) também apresenta uma estrutura com características próprias. Portanto, esse padrão de relacionamento entre engajamento associativo-sindical com a política eleitoral é próprio de categorias específicas e de condições de filiação também particulares, não se aplicando aos demais pólos, como indicado adiante.

O caso de Carlos Abicail pode exemplificar o padrão de carreira militante em que o período anterior à entrada na política é preenchido pelo exercício de cargos de direção sindical e eventual exercício profissional no magistério público estadual, além da ocupação de cargos de direção partidária. Como Deputado, a exemplo de outros com trajeto semelhante, sempre esteve ligado às comissões vinculadas à educação e à cultura. De modo similar, Ideli Salvati, conjuntamente a um trajeto inicial de militância no pólo "progressista” da Igreja Católica (Comunidades Eclesiais de Base), passou a atuar e a exercer cargos de direção no respectivo sindicato de professores em âmbitos local e estadual. Assim, foi uma das fundadoras da CUT estadual, quando passou a disputar cargos políticos eletivos. Em síntese, também teve uma carreira de militante em movimentos sociais, em um período que vai do início da década de 1970 a meados dos anos 1990. Apresentou ainda uma intensa atuação sindical, antes da entrada diretamente na política eleitoral, além de interagir com muita proximidade às questões setoriais relativas à educação. Esse padrão também inclui trajetos como o de Neyde A. da Silva que, na condição de professora estadual, teve uma longa carreira de representante sindical dessa categoria, com o exercício de vários cargos em âmbito estadual e na Confederação Nacional dos Trabalhadores em Educação. Outros apresentam menos peso na militância sindical em seu trajeto e carga maior em outras modalidades de engajamento. Dentre esse grupo, destacam-se as associações de moradores e assemelhadas e movimentos apoiados por igrejas, de modo separado ou conjuntamente. Um dos casos expositivos desse percurso é o de Gilmar A. Machado, filho de "trabalhador rural" que, apesar de ter sido Presidente do sindicato de profes- 
sores em âmbito municipal e de ter participado da direção da CUT em âmbito estadual, integrou também a direção de associação de moradores em bairro periférico e presidiu a Juventude Batista em âmbitos regional e estadual. Militou ainda no Movimento Evangélico Progressista. Portanto, tratase da interseção de um pólo do campo religioso mais "politicista”, homólogo ao pólo "progressista” dos católicos. Esse padrão inclui vários outros, apesar das diferenças secundárias em termos individuais.

Seja como for, as relações dos professores com a militância sindical ou associativa e o peso desse fator na respectiva carreira política dependem diretamente de mais ou de menos intensidade da atuação em outras esferas de atividade. Dentre essas esferas, destacam-se o exercício de cargos públicos de "confiança”; o peso ou a quantidade e o período do exercício de cargos eletivos; a inserção (com mais ou com menos força) em outras modalidades de militância; o peso da carreira de professor stricto sensu e o tempo e o período de seu exercício no desenrolar do ciclo profissional ou vital.

No que concerne ao exercício de cargos públicos de "confiança", os professores e, dentre estes, aqueles de ensino fundamental ou médio, que constituem a maior parte no universo em pauta, não se caracterizam pela forte participação, comparativamente, por exemplo, aos médicos e, inclusive, aos empresários. Tal fato está vinculado a uma conjuntura com uma configuração específica, na qual a entrada na política, dentre outros elementos, tem uma temporalidade própria. Ocorre que a maior parte desses professores é vinculada a partidos que tiveram pouca participação em governos municipais ou estaduais. Porém, mesmo tomando apenas os professores que se posicionam no extremo do pólo dos "trabalhadores", alguns têm na ocupação desse tipo de cargo - particularmente, daquele de Secretário Municipal ou Estadual de educação ou, então, de alguma outra secretaria voltada ao "social" - o preenchimento de uma parte de seu período profissional e, ao que tudo indica, uma forma de acumulação de notabilidade para, posteriormente, utilizá-la nas disputas eleitorais.

Alguns desses professores que tiveram no exercício de cargos públicos de "confiança” um primeiro degrau para o posterior ingresso na política eleitoral, mantiveram uma carreira profissio- nal mais ou menos longa como professor, em geral, conjuntamente à atuação sindical. Outros, como Esther P. Grossi, sempre tiveram uma ligação com o respectivo sindicato apenas na condição de sócio. No caso de Grossi, a carreira profissional caracteriza-se mais como pesquisadora e difusora de novas tecnologias pedagógicas, além da direção de organizações voltadas para esse tipo de atividade. Em outros casos, como o de Antonio C. Biffi, com uma longa carreira de militância sindical e partidária, o exercício de cargos públicos eletivos precede os de "confiança”. Porém, nesses exemplos em que o exercício de cargos eletivos precede os de "confiança", ocorrem muitas diferenças que abrangem as origens sociais e as relações com as diferentes modalidades de militância. Luiz D. Soares personifica um caso de origens socialmente dominantes. Construiu um trajeto de militante estudantil e uma curta carreira de professor secundário, quando se destacou no comando de greves da categoria e no exercício de cargos de direção sindical. Ou seja, nessas condições, o exercício da profissão de professor secundário serve mais como base para a passagem do militância estudantil para o sindical e a ocupação de cargos públicos e de direção partidária. Existem muitos outros casos semelhantes a esse. Em outras situações, o peso do militância sindical é substituído pelos vínculos com instituições da Igreja Católica, particularmente, de seu pólo "progressista”. Esse é o caso de Roque Zimmerman que, simultaneamente à carreira de padre e de professor, foi membro da diretoria do respectivo sindicato. Em outros casos, como o de Tilden J. Santiago, apesar da importância central do pólo "progressista" do catolicismo, a diversidade de esferas de atuação inclui o jornalismo, além do sindicalismo.

Em todo caso, o padrão mais comum de combinação da militância sindical no sindicalismo de professores com outras modalidades de engajamento e de entrada na política consiste naquele que combina militância sindical, exercício de cargos de "confiança" e disputa eleitoral em âmbito local. Certamente, esse dado está associado ao fato de que a maior parte desses professores tem realizado toda ou parte de sua carreira em centros urbanos com alguma participação dos partidos de "esquerda". A maioria começou sua carreira militante como sindicalista (desconsiderando o período estudantil), e o primeiro cargo eletivo, em geral, foi o mais periférico, aquele de Verea- 
dor ${ }^{16}$. Alguns exemplos desse padrão incluem Iara Bernardi, cujo trajeto foi preenchido em sua maior parte como professora de ensino secundário público, além da militância sindical e do exercício de cargos públicos eletivos em âmbito local. Vale citar também Maria do Carmo L. Perpétuo, com a diferença de que incorporou, simultaneamente, o exercício em consultório de psicologia, além de Maria do Rosário Nunes, cuja precocidade na carreira política, após um trajeto de militância sindical, exclui qualquer atuação profissional significativa, dentre muitos outros.

\section{OS POLÍTICOS VINCULADOS A ASSOCI-} AÇÕES-SINDICATOS DE MÉDICOS, ADVOGADOS, ENGENHEIROS E ASSEMELHADOS

Como exemplo do que já foi apresentado, os políticos vinculados a associações-sindicatos de médicos, advogados, engenheiros e assemelhados (113 indivíduos, ou 10,9\% do universo total), em geral, ocupam ou ocuparam cargos de direção na respectiva organização. Desse modo, em sua maior parte, trata-se de dirigentes e não de meros participantes ou sócios. Os cargos mais freqüentemente exercidos são os de direção em âmbito estadual, com mais da metade já tendo exercido este tipo de cargo (56,3\% contra $24,4 \%$ do universo total). A seguir, vêm os cargos de direção nacional (12,6\% contra 9,1\% do universo total) e em âmbito regional ${ }^{17}$. Porém, como algumas das associações têm caráter obrigatório para o exercício profissional (visto que são encarregadas de seu controle, como é o caso da Ordem dos Advogados do Brasil), há uma relativa participação dos que mantêm vínculos apenas na condição de membro ou sócio (10,7\% contra 4,2\% do universo total).

Por formar um conjunto - os indivíduos vinculados a associações-sindicatos de médicos, advogados, engenheiros e assemelhados - que apresenta, inclusive, estatuto profissional baseado na titulação escolar, há uma associação muito forte com determinados cursos de graduação universitária. Trata-se, em geral, de cursos socialmente mais valorizados, vinculados a profissões estabelecidas e com mais afinidades a aplicações “práticas”, dentre os quais se destaca, em primei-

17 Quando um indivíduo ocupou cargos em vários níveis foi considerado apenas o mais alto. ro lugar, o de medicina, que contempla mais de um terço $(38,3 \%)$ dos vinculados a associaçõessindicatos de médicos, advogados, engenheiros e assemelhados, em comparação com pouco mais de um décimo $(10,9 \%)$ do universo total. O segundo curso que se destaca é o de Agronomia (5,4\% contra $2,5 \%$ do universo total). O curso de Direito destaca-se mais pelo montante dos formados e que são vinculados a esse tipo de associações-sindicatos (25,9\%), mas essa quantidade é proporcionalmente inferior ao conjunto dos formados em Direito (29,8\% do universo total). Nesse caso, no que tange à formação universitária, há também uma grande quantidade dos que realizaram cursos de pós-graduação (68\% contra 41,1\% do universo total com algum curso desse tipo), seja de doutorado (13,6\% contra $4,1 \%$ do universo total), de mestrado (8,7\% contra $5,6 \%$ do universo total) ou de especialização (34\% contra $18 \%$ do universo total). Uma outra conseqüência dessa proximidade maior como universo escolar e, mais especificamente, com a titulação universitária, são os que apresentam uma maior quantidade dos que têm alguma publicação (39,6\% contra $33,4 \%$ do universo total, para os com informações disponíveis, que não são exaustivas).

Dessa relação muito direta com a titulação escolar resultam associações também muito específicas com as ocupações durante a "carreira". Quanto a isso, o primeiro ponto que se destaca é o forte vínculo com aqueles cujo trajeto "profissional” é composto pelo exercício da Medicina, liberal ou hospitalar, com a ocupação de cargos públicos de "confiança” e/ou eletivos (35,7\% contra 9,9\% do universo total). Em segundo lugar, destacam-se aqueles cujas principais ocupações consistem no exercício da advocacia em conjunto com a ocupação de cargos públicos de "confiança” e/ou eletivos (15,2\% contra 8,7\% do universo total) e, por fim, pelos que combinam a atuação no rádio-jornalismo com a ocupação de cargos públicos de "confiança” e eletivos. Ou seja, a maioria tem no próprio exercício de cargos públicos, de "confiança" ou eletivos, uma parte considerável de seu trajeto "profissional”. Tudo indica que, como um dos efeitos dessa titulação escolar e, por extensão, de determinados usos de conhecimento técnico -, há um maior peso da ocupação de cargos de "confiança" nos respectivos trajetos "profissionais" e políticos, em detrimento dos cargos públicos eletivos. Há uma proporção muito mais alta dos cujo primeiro cargo "político" foi 
de "confiança” (73,6\% contra 60,7\% do universo total) em detrimento dos cargos eletivos $(17,2 \%$ contra $22,3 \%$ do universo total).

A exemplo de outras categorias de vínculos com as associações-sindicatos, estes também têm uma temporalidade ou estágio no respectivo ciclo das carreiras relativamente específica no que tange à "profissão" política. Isso se manifesta, em primeiro lugar, na idade da entrada ou do exercício no primeiro cargo eletivo. Embora esses que mantêm vínculos com essas associações-sindicatos não se concentrem no extremo mais elevado quanto à idade do primeiro cargo eletivo, a média é bem mais alta do que a do conjunto do universo. A faixa etária do primeiro cargo que mais se associa é a de 41 a 50 anos (42,7\% contra $28,5 \%$ do universo total), seguida pela faixa imediatamente acima, de 51 a 60 anos (13,6\% contra 10,9\% do universo total). Porém, ocorre apenas uma pequena proporção dos que ocuparam o primeiro cargo eletivo na faixa de 19 a 30 anos $(12,7 \%$ contra $20,5 \%$ do universo total) e, embora quantitativamente significativo, mas também em menor proporção, na faixa de 31 a 40 anos (28,2\% contra $37,0 \%$ do universo total).

Por fim, ainda quanto ao trajeto político, referindo-se à ocupação de cargos de direção na respectiva organização associativa ou sindical, há também uma forte associação com a ocupação de postos de direção partidária. Dentre esses cargos, o mais freqüentemente assumido é o de membro do diretório ou da comissão executiva nacional (23,9\% contra $11,8 \%$ do universo total). Em grau menor, vem a ocupação de cargos de direção em diretório ou em comissão executiva em âmbito municipal ou regional. Há ainda uma proporção menor de cargos partidários mais altos, como os de direção, e não apenas participação como integrante, de diretório ou de comissão executiva nacional $(34,51 \%$ contra $49,81 \%$ do universo total).

No contexto das demais categorias, também quanto aos vinculados a associações-sindicatos de médicos, advogados, engenheiros e assemelhados, cabe apresentar, sinteticamente, alguns trajetos exemplares dos principais padrões. Porém, neste caso, por falta de espaço, serão incluídos somente os médicos.

Apesar de muito heterogêneo, o pólo dos médicos contém alguns princípios relativamente simples que regem suas relações com o espaço polí- tico, se comparado com aquele dos "empresários" ou dos "trabalhadores”. O principal desses princípios de divisão é aquele que perpassa o campo médico e serve, em primeiro lugar, como critério de definição da própria Medicina, entre "pública" e "privada" e categorias correlatas ("preventiva” versus "curativa", como "direito" ou "dever do Estado" versus "atividade liberal” ou "privada”, e assim por diante).

Portanto, essa divisão do campo médico, que serve inclusive como critério de definição da Medicina, está diretamente associada e é homóloga às suas relações com o espaço político e com o próprio Estado. Se, por um lado, as relações com as categorias relativas ao campo médico (ocupações no decorrer da carreira profissional, curso universitário realizado, classificação profissional) aproximam o conjunto desses indivíduos, por outro, também os separam. A filiação partidária, as modalidades de vinculação com o engajamento e militância associativa-sindica, o montante do patrimônio, entre outros, ilustram essa afirmação.

Nessas divisões e oposições no campo médico e em suas relações com o espaço político e a ação pública entram em pauta, portanto, diferentes recursos e princípios de legitimação, como a posição social, de origem e de chegada, o forte capital escolar e seu alto grau de aplicabilidade e valorização social e econômica, as diferentes modalidades de exercício profissional e de concepção da própria profissão e suas relações com as divisões e o engajamento político e em outras esferas de atuação e, por fim, com a estrutura de representação corporativa. Ou seja, as oposições que dividem o campo médico e sua "transfiguração" no universo político têm como base diferentes modalidades de exercício e realização profissional, bem como de representação associativasindica. Desse modo, em um extremo dessa oposição - a Medicina Pública vista e defendida como “dever do Estado” pela militância sindical -, há uma proximidade muito forte com o serviço público e, inclusive, com sua definição militante no sentido do funcionalismo público, no caso, constituído pelos médicos como mediadores dos "direitos" da chamada "sociedade civil organizada" ou, então, dos detentores desse "direitos" em geral ${ }^{18}$.

\footnotetext{
18 Para uma análise dessa bipolaridade no campo médico e seus efeitos nas políticas de saúde e previdência social rural, ver Coradini (1989).
} 
No extremo oposto, onde se situam proprietários de hospitais ou clínicas particulares, apesar de sua vinculação com a titulação universitária e com alguma deontologia profissional, a Medicina é concebida e posta em prática como tendo uma dimensão de "empresa econômica”. Portanto, se no caso anterior o exercício profissional está associado ao serviço público, neste último, isso ocorre com as atividades privadas, sejam "liberais" ou "empresariais". Evidentemente, esses dados têm implicações diretas na apropriação dos referenciais em voga e na defesa de determinadas formulações de políticas. Porém, mesmo nesses casos extremos, a transfiguração no espaço político desses interesses e modalidades de realização profissional e social não é direta, visto que entram em pauta as diferentes lógicas em que esses indivíduos estão inseridos, em que se destacam aquelas das disputas eleitorais, da pressão corporativa ou, ainda, as centradas na formulação e implementação de políticas de saúde ou em termos mais gerais.

Entre essas duas situações polares da Medicina como serviço público ou "social" e como "empresa econômica”, todavia, ocorrem muitas outras modalidades de exercício e de seu uso como base de legitimação profissional, com mais ou menos eficácia em sua reconversão em capital associativo e político. Uma das principais dessas modalidades é a utilização do exercício médico associado à filantropia ou à assistência que, via de regra, é operada em combinação com a Medicina Privada, como os trajetos expostos posteriormente indicam. Uma outra modalidade que se destaca é a do exercício médico em combinação com a ocupação de cargos públicos, eletivos ou de "confiança” em âmbito local, em uma espécie de reconversão de assistência médica em notabilidade. Ainda que de modo pouco significativo em termos estritamente quantitativos, mesmo tomando apenas o extremo desse pólo dos médicos, ocorrem também casos daqueles que se destacam por intermédio de uma carreira de professor universitário ou de pesquisador. O tipo de vinculação e as temporalidades nas relações do trajeto profissional com a carreira política são variáveis para cada caso.

Portanto, apesar das semelhanças daqueles que se situam em algum desses pólos, também ocorrem fortes diferenças, e uma das mais profundas é relativa à inserção social e às modalidades de engajamento e militância. Esse processo abrange a militância prévia, como aquela em organizações estudantis ou de outro tipo; a militância associativasindica, que, no caso, é forte e tende a ter início ainda na fase estudantil, por exemplo, por meio das organizações de médicos “residentes”; por fim, sem qualquer pretensão de exaustão, entram em pauta os efeitos dessa militância anterior na carreira "profissional”, seja orientando-a para um padrão mais associado ao serviço público ou, então, à medicina liberal, seja se constituindo em base para a ocupação de cargos públicos de "confiança” e sua eventual reconversão em recursos eleitorais.

Como um caso exemplar da versão mais "pública” do trajeto profissional de médico e sua vinculação com a esfera política que tem como base o serviço público e a militância associativasindica, pode ser tomado Arlindo Chinaglia. Seu trajeto profissional está centrado no exercício da Medicina Pública mas, simultaneamente, manteve uma carreira de intensa militância. Ela começou na Associação dos Médicos Residentes ${ }^{19}$, passando para o sindicato médico em âmbito estadual, a vice-presidência da Federação Nacional dos Médicos, a presidência da CUT do estado de São Paulo e a participação na sua direção nacional. Atuou também na militância e no exercício de cargos de direção partidária (PT), por meio da qual passou a disputar eleições e a obter cargos políticos eletivos. Portanto, nesse tipo de trajeto, a carreira de militância estudantil, corporativa, partidária e a defesa da Medicina como um "direito" e serviço público praticamente se confundem e são interdependentes. De modo semelhante, embora em outro partido (PCdoB), Jandira Feghali, ainda na fase estudantil, se engajou no movimento dos médicos residentes, sendo Presidente da respectiva associação nacional e do sindicato médico do Rio de Janeiro, além da associação dos funcionários do hospital público em que atuava e de uma outra esfera de militância, como uma das fundadoras da União das Mulheres do Rio de Ja-

19 Para informações mais detalhadas sobre o desenvolvimento do sindicalismo médico no Brasil, ligado à Medicina Pública e tendo o Rio de Janeiro como base geográfica inicial, em oposição ao esquema norte-americano das associações e sua vinculação com a medicina "liberal”, expostas por um de seus protagonistas, ver Mello (1983). Para mais detalhes sobre a formação e o desenvolvimento do Movimento de Renovação Médica, também expostos por um de seus protagonistas, que exemplifica, inclusive, a utilização de esquemas oriundos das Ciências Sociais nesse tipo de luta, ver Campos (1988). 
neiro. Com exceção dessa última esfera de militância, mais diretamente voltada para problemas de gênero, esse é um padrão que inclui muitos outros médicos do universo em pauta, dentre os quais, Jamil Murad, Agnelo S. Queiroz, Eduardo Jorge M. A. Sobrinho e Ângela M. Guadagnin. Isso, no entanto, não exclui diferenças significativas na composição e no respectivo peso de diferentes esferas de militância. No caso de Eduardo Jorge M. A. Sobrinho, por exemplo, há um peso maior da militância estudantil em organizações de "esquerda" clandestina na fase inicial de seu trajeto, da atuação como médico sanitarista na carreira profissional e como mediador de demandas por políticas de assistência médica para a população residente na periferia urbana. Quanto à Ângela M. Guadagnin, além de outras diferenças, destaca-se o peso do engajamento inicial nas "pastorais" da igreja católica, em combinação com a atuação em consultório particular, dentre outras atividades.

Passando para o extremo oposto, aquele da Medicina praticada como atividade "empresarial" ou, pelo menos, "privada” ou "liberal”, o primeiro aspecto que se ressalta é que, se, por um lado, quantitativamente, essa modalidade abrange a maior parte dos médicos que compõem o universo em pauta, por outro, praticamente nunca aparece em termos exclusivos. Como já foi indicado no item anterior, muitos políticos, inclusive, apresentam-se como "médico e empresário", mas, nesses casos, a condição de empresário significa, em geral, a ampliação dos investimentos, a partir da condição de "herdeiro" e não como transformação da própria atividade médica em empreendimento empresarial no sentido estritamente econômico. Além disso, por razões compreensíveis, inclusive pela pouca quantidade numérica dos envolvidos, além de prováveis problemas de legitimação, a chamada "Medicina de grupo" aparece mais como grupo de interesse do que como base eleitoral de algum segmento político ${ }^{20}$.

20 Como um bom exemplo da diversidade de interesses organizados - da Medicina de "Grupo", dos planos médicos, da Medicina “Liberal”, da Medicina Pública, das organizações de representação de diferentes categorias de "trabalhadores” dos serviços médicos, de organizações de representação dos "pacientes", e assim por diante - pode ser tomado o processo da Comissão Parlamentar de Inquérito (CPI) dos planos de saúde, da qual foi relator o Deputado Ribamar Alves, realizada em 2003. Ver O Globo (18.nov.2003)
Normalmente, no que tange ao pólo "médico" do universo em pauta, a prática da Medicina como empresa econômica aparece conjuntamente a outras modalidades de exercício médico, como aquele em hospitais ou organizações de assistência pública e freqüentemente associada a cargos públicos de "confiança”, além dos investimentos econômicos em setores externos à Medicina. Esse é o caso, dentre outros, de Ursicino P. de Queiroz que, depois de formado, manteve uma carreira de exercício médico e de direção de hospitais particulares e filantrópicos. Simultaneamente, passou a ser sócio de uma empresa médica e, quanto ao engajamento associativo, sua principal participação consiste naquela de membro da associação de hospitais em âmbito estadual, além de organizações de prefeitos, chegando a ser vice-Presidente da Confederação Nacional de Municípios (CNM). De modo semelhante, Alceste M. de Almeida compõe sua carreira, por uma lado, com a atuação como médico em organismos públicos e o exercício de cargos públicos de "confiança"; por outro lado, suas condições social e "profissional" têm como base, também, a propriedade de hospital. A combinação do exercício médico em clínica ou hospital particular ou filantrópico com o exercício de cargos públicos de "confiança” e eletivos, particularmente em âmbitos local e regional, inclui muitos outros casos, como Antonio S. Venzon, Geraldo R. Pereira, Evilasio C. de Farias, dentre outros. Porém, o peso desses componentes e, fundamentalmente, dos cargos em âmbito local são muito variáveis, diferentemente do pólo da Medicina "Pública", mas homogêneo quanto à importância da militância e dos cargos públicos vinculados ao exercício da Medicina.

De todas as esferas de ação e princípios de legitimação postos em prática por esses médicos do pólo privatista, em conjunto com o exercício profissional ou em outras modalidades de engajamento, destacam-se a filantropia ou a assistência. Estas, contudo, no que tange ao universo em pauta, composto por políticos de âmbito nacional, não se restringem à atuação profissional, naquele esquema dicotômico típico da Medicina "privada" ou "liberal”. Ou seja, uma tem orientação voltada para a população melhor situada socialmente, que se constitui em "cliente; e outra tem orientação voltada aos pobres, população carente ou algo semelhante, pela filantropia ou pelo trabalho social, com ou sem apoio direto de políticas governamentais e de outras instituições, 
como organizações apoiadas por igrejas ${ }^{21}$. No caso em pauta, apesar de, evidentemente, a prática médica como assistência e sua reconversão em trunfo eleitoral serem correntes, trata-se, principalmente, de ocupantes de cargos de direção em organizações filantrópicas ou assistenciais. Algumas dessas organizações têm um caráter mais geral, outras podem ter como "causa” e públicoalvo categorias sociais muito específicas, como os portadores de alguma "deficiência” determinada.

Para tomar um caso clássico daqueles com trajeto centrado no exercício de cargos de direção em organizações filantrópicas, basta observar o percurso de Darcisio P. Perondi: como principal ocupação profissional anterior à entrada na política eleitoral, atuou como médico em um hospital filantrópico, além de organismos públicos de forma complementar. Pouco tempo depois, passou a presidir a associação filantrópica proprietária do hospital e, na ampliação desse tipo de atividade de direção de organizações filantrópicas, tornou-se o Presidente da Federação das Santas Casas e Hospitais Filantrópicos do Rio Grande do Sul e VicePresidente da Confederação das Misericórdias do Brasil. Evidentemente, a representação de associações filantrópicas não esgota as bases eleitorais desse tipo de político e médico, inclusive, porque está em pauta também a mediação de interesses regionais, além daqueles de ordem corporativa, setorial, dentre outras. Porém, é importante notar que, em casos como esse, um determinado tipo de exercício médico é representado em associação com a filantropia, ou seja, uma atividade que tem como base uma determinada moral e que mantêm afinidades com esse tipo de exercício profissional $^{22}$

De modo semelhante, mas com concentração maior em uma "causa” particular, Eduardo L. B. Barbosa tem em organizações filantrópicas dirigidas aos “excepcionais” o principal compo-

21 Sobre os diferentes princípios que respaldam as políticas de saúde e assistência social no Brasil, como a condição de “cidadão" definido relativamente ao Estado, aquela da filantropia com base em ideologias religiosas e as relações de reciprocidade típicas do clientelismo, ver Coradini (1994).

22 Para uma discussão mais geral entre o exercício profissional do direito e a filantropia, nos Estados Unidos e na América Latina, ver Dazalay e Garth (2002). nente da carreira profissional, associativa e fonte de recursos políticos. Concomitantemente ao exercício profissional como médico pediátrico no interior de Minas Gerais em organizações filantrópicas e públicas, foi diretor da Associação de Pais e Amigos de Excepcionais (Apae) local por quase duas décadas. Na ampliação desse tipo de atividade, foi fundador da Federação das Apaes em âmbito estadual e da respectiva federação nacional. Desses cargos resultou, inclusive, sua indicação como representante da "sociedade civil" no Conselho Nacional de Defesa dos Direitos da Criança, além de outros postos associados à "causa".

\section{CONSIDERAÇÕES FINAIS}

Como parece ter ficado evidente, no caso brasileiro, o grau de vinculação dos políticos de atuação nacional com associações-sindicatos de diferentes tipos cresceu no período atual. Adicionalmente, é possível estabelecer as relações desse fato com os indicadores relativos aos respectivos trajetos sociais e políticos. Tal quadro permite concluir que, com a intensificação da concorrência eleitoral posterior ao regime autoritário, houve um aumento da utilização de capital associativo como recurso eleitoral, pelo menos para boa parte dos candidatos vencedores das eleições nacionais.

Essa constatação parece contrastar com experiências de outros países, embora possa aproximar-se de outros casos. Porém, frente à falta de estudos e informações sistemáticas relativamente a outros contextos nacionais e à fase atual do desenvolvimento do trabalho, a melhor opção talvez seja restringir-se a um caso nacional, na esperança de, futuramente, dispor de condições para análises comparativas. Essa opção decorre também de uma postura metodológica que procura evitar qualquer dedução e que, como já mencionado, pressupõe que os resultados ou tendências das relações entre os engajamentos associativo e partidário ou eleitoral dependem de configurações específicas e não de alguma determinação geral. Somente após a realização de trabalhos comparativos mais abrangentes poder-se-ia vislumbrar alguma generalização sobre as relações entre engajamento associativo e política eleitoral.

Em todo caso, os resultados obtidos até aqui reforçam a necessidade de considerar os diferentes tipos de recursos e lógicas sociais nos processos eleitorais ou políticos em geral. Assim, mais do que a quantidade ou a intensificação de alguma 
modalidade de engajamento e respectivos recursos utilizados, o principal problema para o estudo passa a ser suas relações de interdependência, de eventual complementaridade ou de exclusão e seus efeitos nos trajetos e nas práticas em nome da representação política.

Odaci Luiz Coradini (coradini@vortex.ufrgs.br) é Mestre em Ciência Política pela Universidade Federal de Minas Gerais (UFMG), Doutor em Antropologia Social pela Universidade Federal do Rio de Janeiro (UFRJ) e Professor Adjunto do Departamento de Ciência Política e do Programa de Pós-Graduação em Ciência Política da Universidade Federal do Rio Grande do Sul (UFRS).

\section{REFERÊNCIAS BIBLIOGRÁFICAS}

ABREU, A. A. (coord.). 2004. Dicionário histórico-biográfico brasileiro pós-1930. $2^{\mathrm{a}}$ ed. Rio de Janeiro : Fundação Getúlio Vargas.

BADIE, B. \& HERMET, G. 1993. Política comparada. Ciudad de México : Fondo de Cultura Econômica.

BADIE, B. 1994. Le développement politique. $5^{\mathrm{e}}$ ed. Paris : Economica.

BEZERRA, M. O. 1999. Em nome das "bases": política, favor e dependência pessoal. Rio de Janeiro : Relume-Dumará.

BEST, H. \& COTTA, M. (eds.). 2000. Parliamentary Representatives in European Countries. Oxford : Oxford University.

BIRNBAUM, P. 1994. Les sommets de l'État : essai sur l'Élite du pouvoir en France. $2^{\mathrm{e}}$ ed. Paris : Seuil.

BORCHERT, J. \& ZEISS, J. (eds.). 2003. The Political Class in Advanced Democraties. Oxford : Oxford University.

BOURDIEU, P. 1981. La représentation politique : éléments pour une théorie du champ politique. Actes de la Recherche en Sciences Sociales, Paris, n. 36-37, p. 3-24, fev.-mar.

1989. La noblesse d'État : grandes écoles et esprit de corps. Paris : Minuit.

BRAUD, P. 1985. Du pouvoir em general au pouvoir politique. In : GRAWITZ, M. \& LECA, J. (dirs.). Traité de Science Politique. V. 1 : La science politique, science sociale. L'ordre politique. Paris : PUF.

CAMPOS, G. W. S. 1988. Os médicos e a política de saúde : entre a estatização e o empresariamento. A defesa da prática liberal da medicina. São Paulo : Hucitec.
COLLOVALD, A. \& GAÏTI, B. 1990. Discours sous surveillances : Le social à l'Assemblée. In : GAXIE, D. (dir.). Le "social” transfigure : sur la représentation politique des préoccupations sociales. Paris : PUF.

CORADINI, O. L. 1989. Representações sociais e conflitos nas políticas de saúde e previdência social rural. Rio de Janeiro. Tese (Doutorado em Antropologia Social). Universidade Federal do Rio de Janeiro.

1994. "Crise” conjuntural de políticas "sociais” ou de referenciais? Ensaios FEE, Porto Alegre, v. 15, n. 2, p. 489-501.

1996. Ambivalências na representação de classe e a noção de "trabalhador rural". In : NAVARRO, Z. (org.). Política, protesto e cidadania no campo : as lutas sociais dos colonos e dos trabalhadores rurais no Rio Grande do Sul. Porto Alegre : UFRGS.

2005. Engajamento associativo, "participação" e representação política no período recente no Brasil. Relatório de Pesquisa para o CNPq. Porto Alegre : digit.

DEZALAY, Y. \& GARTH, B. G. 2002. La mondialisation des guerres de palais : la restructuration du pouvoir d'État en Amérique Latine. Entre notables du droit et "Chicago Boys”. Paris : Seuil.

FOREWAKER, J. 1982. A luta pela terra : a economia política da fronteira pioneira no Brasil. de 1930 aos dias atuais. Rio de Janeiro : Zahar.

GARRIGOU, A. 2001. Les élites contre la République : Science Po et l'ENA. Paris : La Découverte.

GAXIE, D. \& OFFERLÉ, M. 1985. Les militants syndicaux et associatifs au pouvoir? Capital 
social collectif et carrière politique. In : BIRNBAUM, P. (dir.) Les élites socialistes au pouvoir : les dirigeants socialistes face à l’Etat : 1981-1995. Paris : PUF.

GAXIE, D. 1980. Les logiques du recrutment politique. Revue Française de Science Politique, Paris, v. 30, n. 1, p. 5-45, fev.

IBGE. 2003. Pesquisa nacional por amostra de domicílios 2002. Microdados. Rio de Janeiro : Instituto Brasileiro de Geografia e Estatística.

LAGROYE, J. 2003. Les processus de politisation. In : (dir.). La politisation.

Paris : Belin.

LAGROYE, J.; FRANÇOIS, B. \& SAWICKI, F. 2002. Sociologie Politique. $4^{\mathrm{e}}$ ed. Paris : Presses de Sciences Po.

MELLO, C. G. 1983. A medicina e a realidade brasileira. Rio de Janeiro : Achiamé.
OFFERLÈ, M. 1998. Sociologie des groupes d'interets. Paris : Montchrestien.

SANTOS, W. G. 1979. Cidadania e justiça. Rio de Janeiro : Campus.

SAWICKI, F. 1997. Les réseaux du Parti Socialiste : Sociologie d'un millieu partisan. Paris : Belin.

1999. Classer les hommes politiques. Les usages des indicateurs de position sociale pour la compréhension de la professionalisation politique. In : OFFERLÉ, M. (dir.). La profession politique : $\mathrm{XIX}^{\mathrm{e}}-\mathrm{XX}^{\mathrm{e}}$ siècles. $\mathrm{Pa}-$ ris : Belin.

SIMÉANT, J. 2003. Un humanitaire “apolitique”? Démarcations, socialisations au politique et espaces de la réalisation de soi. In : LAGROYE, J. (dir.). La politisation. Paris : Belin.

VIGNA, E. 2001. A bancada ruralista : um grupo de interesse. Brasília : INESC.

\section{OUTRAS FONTES}

O Globo, Rio de Janeiro, 18.nov.2003. 
ASSOCIATIVE/SYNDICATE INVOLVEMENT AND RECRUITING OF POLITICAL ELITES: RECENT TENDENCIES IN BRAZIL

\section{Odaci Luiz Coradini}

Based on the confirmation of the continuous increase in the number of politicians who are active at the national level (federal representatives, senators and ministers) linked to some type of association or syndicate, we examine how this is related to the respective social trajectories and positions occupied within political space. For these purposes, we consider politicians linked to the associations and syndicates of urban and rural workers, of civil servants, university faculty and businessmen, for people who were elected to office between 1994 and 2003. Our main hypothesis refers to the increased use of associative capital that can be observed in conjunction with the intensification of electoral competition in the aftermath of the authoritarian regime; it suggests that electoral processes bring together a variety of resources and principles of legitimation and representation. Modes of reconverting associative capital into political resources and dynamics of electoral politics/associative involvement relations are not seen as a consequence of some general principles but as part of specific configurations.

KEYWORDS: political elites; associative capital; political involvement and militancy; political representation. 
ENGAGEMENT ASSOCIATIF/SYNDICAL ET RECRUTEMENT D’ÉLITES POLITIQUES: NOUVELLES TENDANCES AU BRÉSIL

\section{Odaci Luiz Coradini}

En fonction de la croissance permanente du nombre de politiciens agissant sur le plan national (députés, senateurs et ministres) qui sont liés à une association ou à un syndicat, nous examinerons les relations de ces faits non seulement à l'aide de leurs trajets sociaux, mais aussi de leurs positions dans l'espace politique. A cet effet, il sera pris en compte les politiciens liés à des associations/ syndicats de travailleurs urbains, ruraux, de fonctionnaires, d'enseignants et d'entrepreneurs, élus de 1994 à 2003. L'hypothèse la plus importante concernant l'accroit d'utilisation du capital associatif, c'est que ces processus électoraux agrégent de différents recours et de principes de légitimation et de représentation. Les modalités de cette conversion de capital associatif en recours politiques et le mouvement des relations entre l'engagement associatif et la politique électorale ne résultent pas d'une règle générale, mais de configurations particulières.

MOTS-CLÉS: élites politiques; capital associatif; engagement et travail politique; représentation politique. 